\title{
Hematologically important mutations: Bilirubin UDP-glucuronosyltransferase gene mutations in Gilbert and Crigler-Najjar syndromes
}

\author{
Elísio Costa \\ Submitted 29 October 2005; revised 31 October 2005 \\ (Communicated by E. Beutler, M.D., 31 October 2005)
}

Escola Superior de Saúde do Instituto Politécnico de Bragança, Avenida D. Afonso V, 5300-121 Bragança, Portugal

\begin{abstract}
Gilbert and Crigler-Najjar syndromes are familial unconjugated hyperbilirubinemias caused by genetic lesions involving a single complex locus encoding for bilirubin UDP-glucuronosyltransferase (UGT1A1) gene. Over the last years, a number of different mutations affecting this gene have been characterized. In this report is provided a summary of reported Gilbert and Crigler-Najjar syndromes-associated UGT1A1 gene mutations. (C) 2005 Elsevier Inc. All rights reserved.
\end{abstract}

Keywords: Gilbert syndrome; UGT1A1; Hyperbilirubinemia; Mutations

Water-insoluble bilirubin, which results from breakdown products of heme, is a toxic compound. Hepatic glucuronization of this insoluble bilirubin is catalyzed by isoenzyme $1 \mathrm{~A} 1$ of UDP-glucuronosyltransferase (UGT1A1), which is essential for efficient biliary excretion of bilirubin [1,2]. Mutations in the UGT1A1 gene (UGT1A1; MIM\#191740) are responsible for both Gilbert and Crigler-Najjar syndromes. Genetic alterations causing absence, or severe reduction, of UGT1A1 enzymatic activity, result respectively in Crigler-Najjar syndrome type I and type II [1-5]. The clinical classification of Crigler-Najjar syndrome types I and II is based on the bilirubin levels, the presence of kernictus and the reduction of the bilirubin levels upon administration of phenobarbital or other enzyme-inducing agents $[3,4]$. Type I Crigler-Najjar syndrome is characterized by almost complete absence of UGT1A1 enzyme activity, with serum bilirubin levels of $340-685 \mu \mathrm{mol} / 1$ or higher and is refractory to phenobarbital treatment. In type II Crigler-Najjar syndrome, enzyme activity is severely reduced, with a serum bilirubin level of 100-340 $\mu \mathrm{mol} / \mathrm{l}$. Enzyme activity can be induced by phenobarbital treatment $[3,4]$. Mild hyperbilirubinemia, usually less than $50 \mu \mathrm{mol} / \mathrm{l}$, is associated with Gilbert Syndrome and thought to reflect a small reduction in UGT1A1

E-mail address: elisio.costa@ipb.pt. activity (approximately $30 \%$ ) [2]. UGT1A1 protein is encoded by five consecutive exons located at the $3^{\prime}$ end of the UGT1A locus [5].

Gilbert and Crigler-Najjar Syndromes gene mutations are shown in Table 1. The nucleotide numbers shown in this table are based on the cDNA sequence in the GenBank, accession number NM_000463.2. The recommended numbering convention used in this tabulation assigns " 1 " to the A of the initiator ATG codon. Mutations are described according to the recommendations of the Human Genome Variation Society (www.hgvs.org).

\section{References}

[1] M. Sampietro, A. Iolascon, Molecular pathology of Crigler-Najjar type I and II and Gilbert's syndrome, Haematologica 84 (1999) $150-157$.

[2] J. Borlak, T. Thum, O. Landt, K. Erb, R. Hermann, Molecular diagnosis of a familial nonhemolytic hyperbilirubinemia (Gilbert syndrome) in healthy subjects, Hepatology 32 (2000) 792-795.

[3] G.R. Lee, T.C. Bithell, J. Foerster, J.W. Athens, J.N. Lukens, Wintrobe's Clinical Haematology, 9th ed., Lea and Febiger, Philadelphia, 1993.

[4] D.G. Nathan, S.H. Orking, Nathan and Oski's Haematology of Infancy and Childhood, 5th ed., WB Sanders Company, Philadelphia, 1998.

[5] P.J. Bosma, N.R. Chowdhury, B.G. Goldhoorn, et al., Sequence of exons and the flanking regions of human bilirubin-UDP-glucurono- 
Table 1

Bilirubin UDP-glucuronosyltransferase gene mutations in Gilbert and Crigler-Najjar syndromes

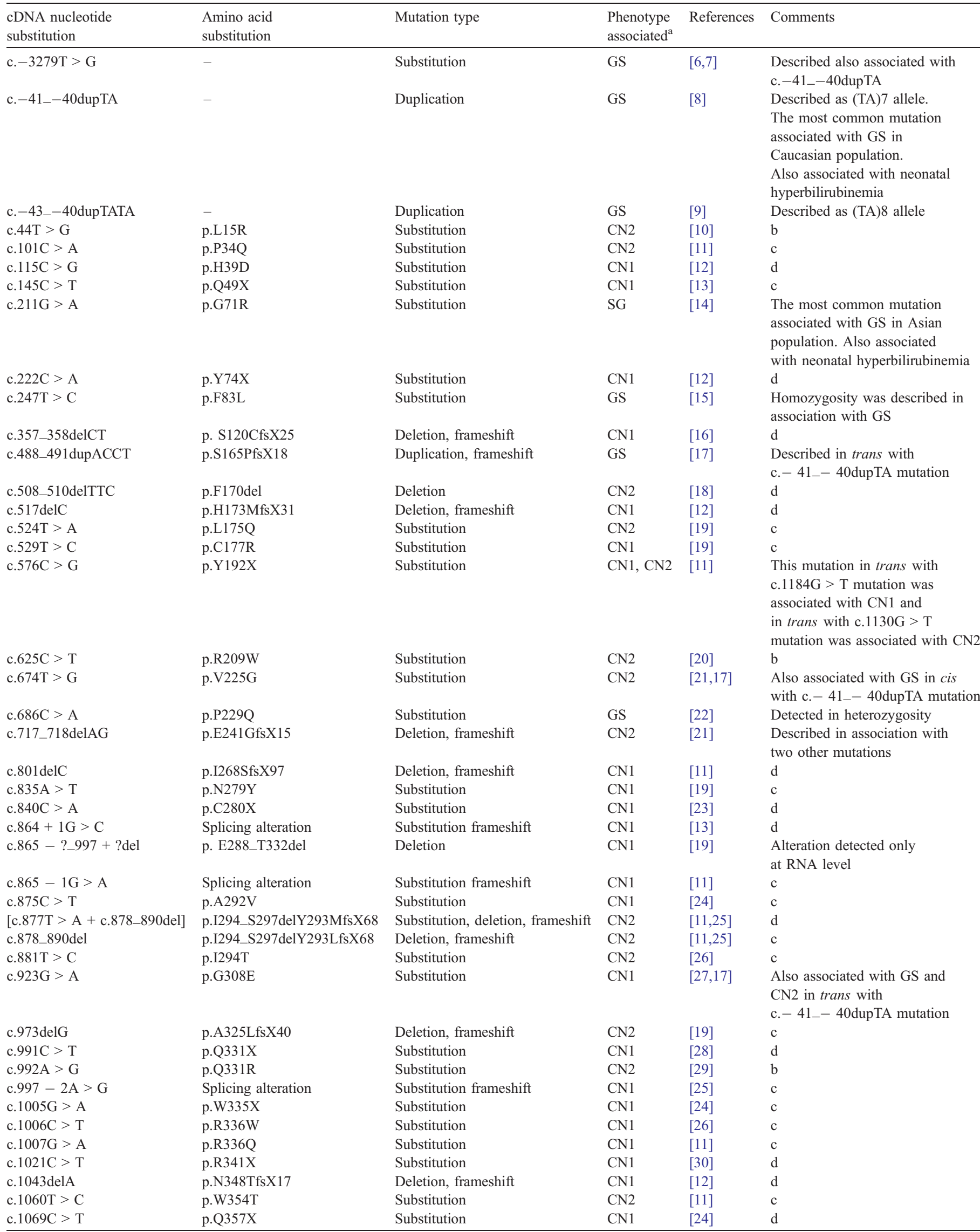


Table 1 (continued)

\begin{tabular}{|c|c|c|c|c|c|}
\hline $\begin{array}{l}\text { cDNA nucleotide } \\
\text { substitution }\end{array}$ & $\begin{array}{l}\text { Amino acid } \\
\text { substitution }\end{array}$ & Mutation type & $\begin{array}{l}\text { Phenotype } \\
\text { associated }^{\mathrm{a}}\end{array}$ & References & Comments \\
\hline c. $1070 \mathrm{~A}>\mathrm{G}$ & p.Q357R & Substitution & CN1 & {$[24]$} & $\mathrm{d}$ \\
\hline c. $1085-1 \mathrm{G}>\mathrm{A}$ & Splicing alteration & Substitution & CN1 & {$[25]$} & $\mathrm{c}$ \\
\hline c. $1099 \mathrm{C}>\mathrm{G}$ & p.R367G & Substitution & GS & {$[22]$} & Detected in heterozygosity \\
\hline c. $1102 \mathrm{G}>\mathrm{A}$ & p.A368T & Substitution & CN1 & {$[24]$} & $\mathrm{c}$ \\
\hline c. $1124 \mathrm{C}>\mathrm{T}$ & p.S375F & Substitution & CN1 & [27] & $\mathrm{d}$ \\
\hline c. $1127 \mathrm{~A}>\mathrm{G}$ & p.H376R & Substitution & $\mathrm{CN} 2$ & [12] & $\mathrm{c}$ \\
\hline c. $1130 \mathrm{G}>\mathrm{T}$ & p.G377V & Substitution & $\mathrm{CN} 2$ & [12] & $\mathrm{d}$ \\
\hline c. $1143 \mathrm{C}>\mathrm{G}$ & p.S381R & Substitution & CN1 & {$[24]$} & $\mathrm{d}$ \\
\hline c.1157_1158indelsGT & p.V386G & Insertion, deletion & CN1 & {$[16]$} & $\mathrm{d}$ \\
\hline c. $1159 \mathrm{C}>\mathrm{T}$ & p.P387S & Substitution & CN1 & [11] & $\mathrm{c}$ \\
\hline c. $1184 \mathrm{G}>\mathrm{T}$ & p.G395V & Substitution & CN1 & [11] & $\mathrm{d}$ \\
\hline c.1186delG & p.D396IfsX15 & Deletion, frameshift & $\mathrm{CN} 2$ & {$[31]$} & $\mathrm{c}$ \\
\hline c. $1198 \mathrm{~A}>\mathrm{G}$ & p.N400D & Substitution & $\mathrm{CN} 2$ & {$[32]$} & $\begin{array}{l}\text { Associated with homozygosity } \\
\text { for the c. }-43_{-}-40 \text { dupTATA } \\
\text { mutation }\end{array}$ \\
\hline c. $1201 \mathrm{G}>\mathrm{C}$ & p.A401P & Substitution & CN1 & {$[24]$} & $\mathrm{c}$ \\
\hline c. $1207 \mathrm{C}>\mathrm{T}$ & p.R403C & Substitution & $\mathrm{CN} 2$ & [11] & c \\
\hline c.1220delA & p.K407RfsX4 & Deletion, frameshift & CN1 & [12] & $\mathrm{c}$ \\
\hline c. 1223 insG & p.A409SfsX12 & Insertion, frameshift & CN1 & {$[24]$} & $\mathrm{c}$ \\
\hline c. $1282 \mathrm{~A}>\mathrm{G}$ & p.K428E & Substitution & CN1 & {$[24]$} & $\mathrm{c}$ \\
\hline c. $1304+1 \mathrm{G}>\mathrm{T}$ & Splicing alteration & Substitution & CN1 & {$[11]$} & $\mathrm{c}$ \\
\hline c. $1309 \mathrm{~A}>\mathrm{T}$ & p.K437X & Substitution & CN1 & {$[24]$} & $\mathrm{c}$ \\
\hline c. $1381 \mathrm{~T}>\mathrm{C}$ & p.W461R & Substitution & CN1 & {$[33]$} & $\mathrm{d}$ \\
\hline c. $1388 \mathrm{~A}>\mathrm{C}$ & p.E463A & Substitution & $\mathrm{CN} 2$ & {$[34]$} & $\begin{array}{l}\text { Associated with homozygosity } \\
\text { for the c. }-41_{-}-40 \text { dupTA } \\
\text { mutation }\end{array}$ \\
\hline c. $1433 \mathrm{C}>\mathrm{A}$ & p.A478D & Substitution & $\mathrm{CN} 2$ & {$[11]$} & $\mathrm{b}$ \\
\hline c. $1448 \mathrm{G}>\mathrm{A}$ & p.W483X & Substitution & CN1 & {$[12]$} & $\mathrm{d}$ \\
\hline c. $1449 \mathrm{G}>\mathrm{A}$ & p.W483X & Substitution & $\mathrm{CN} 1$ & {$[12]$} & $\mathrm{d}$ \\
\hline c. $1456 \mathrm{~T}>\mathrm{G}$ & p.Y486D & Substitution & $\mathrm{CN} 2$ & {$[35]$} & $\begin{array}{l}\text { Associated with homozygosity } \\
\text { to the c. } 211 \mathrm{G}>\text { A mutation }\end{array}$ \\
\hline c. $1463 \mathrm{C}>\mathrm{T}$ & p.S488F & Substitution & CN1 & {$[28]$} & $\mathrm{d}$ \\
\hline c. $1487 \mathrm{~T}>\mathrm{A}$ & p.L496X & Substitution & CN1 & {$[12]$} & $\mathrm{c}$ \\
\hline
\end{tabular}

b) Homozygosity for this mutation was described in association with $\mathrm{CN} 2$.

c) This mutation was described in trans with other mutation.

d) Homozygosity for this mutation was described in association with CN1.

GS: Gilbert syndrome. CN1: Crigler-Najjar Syndrome type I. CN2: Crigler-Najjar Syndrome type II.

${ }^{a}$ The phenotype associated is related with the first description of the mutation.

syltransferase gene complex and identification of a genetic mutation in a patient with Crigler-Najjar syndrome type I, Hepatology 15 (1992) 941-947.

[6] J. Sugatani, K. Yamakawa, K. Yoshinari, T. Machida, H. Takagi, M. Mori, et al., Identification of a defect in the UGT1A1 gene promoter and its association with hyperbilirubinemia, Biochem. Biophys. Res. Commun. 292 (2002) $492-497$.

[7] E. Costa, E. Vieira, R. Santos, The polymorphism c.-3279T $>$ G in the phenobarbital-responsive enhancer module of the bilirubin UDP-glucuronosyltransferase gene is associated with Gilbert syndrome, Clin. Chem. 51 (2005) 2204-2206.

[8] P.J. Bosma, J.R. Chowdhury, C. Bakker, S. Gantla, A. Boer, B.A. Oostra, et al., The genetic basis of the reduced expression of bilirubin UDPglucuronosyltransferase 1 in Gilbert syndrome, N. Eng. J. Med. 333 (1995) 1171-1175.

[9] A. Iolascon, M.F. Faienza, M. Centra, S. Storelli, et al., (TA) 8 allele in the UGT1A1 gene promoter of a Caucasian with Gilbert's syndrome, Haematologica 84 (1999) 106-109.

[10] J. Seppen, E. Steenken, D. Lindhout, P.J. Bosma, R.P. Elferink, A mutation which disrupts the hydrophobic core of the signal peptide of bilirubin UDP-glucuronyltransferase, an endoplasmatic reticulum membrane protein, causes Crigler-Najjar type II, FEBS Lett. 390 (1996) 294-298.

[11] V. Servedio, M. d'Apolito, N. Maiorano, B. Minuti, F. Torricelli, F. Ronchi, et al., Spectrum of UGT1A1 mutations in Crigler-Najjar (CN) syndrome patients: identification of twelve novel alleles and genotypephenotype correlation, Hum. Mutat. 25 (2005) 325.

[12] A. Kadakol, S.S. Ghosh, B.S. Sappal, G. Sharma, J.R. Chowdhury, N.R. Chowdhury, Genetic lesions of bilirubin uridine-diphosphoglucuronate glucuronosyltransferase (UGT1A1) causing Crigler-Najjar and Gilbert syndromes: correlation of genotype to phenotype, Hum. Mutat. 16 (2000) 297-306.

[13] S. Gantla, C.T. Bakker, B. Deocharan, N.R. Thummala, J. Zweiner, M. Sinaasappel, J. Roy Chowdhury, P.J. Bosma, N. Roy Chowdhury, Splice-site mutations: a novel genetic mechanism of Crigler-Najjar syndrome type 1, Am. J. Hum. Genet. 62 (1998) 585-592.

[14] Y. Maruo, S. Wada, K. Yamamoto, H. Sato, T. Yamano, M. Shimada, A case of anorexia nervos with hyperbilirubinaemia in a patient homozygous for a mutation in the bilirubin UDP/glucuronosyltransferase gene, Eur. J. Pediatr. 158 (1999) 547-549.

[15] 3R. Sutomo, V. Laosombat, A.H. Sadewa, N. Yokoyama, H. Nakamura, M. Matsuo, H. Nishio, Novel missense mutation of the UGT1A1 gene in Thai siblings with Gilbert's syndrome, Pediatr. Int. 44 (2002) 427-432.

[16] M. Ciotti, R. Obaray, M.G. Martin, I.S. Owens, Genetic defects at the UGT1 locus associated with Crigler-Najjar type I disease, including a prenatal diagnosis, Am. J. Med. Genet. 68 (1997) 173-178.

[17] E. Costa, E. Vieira, M. Martins, J. Saraiva, E. Cancela, M. Costa, R. Bauerle, T. Freitas, J.R. Carvalho, E. Santos-Silva, J. Barbot, R. dos Santos, Analysis of the UDP-glucuronosyltransferase gene in Portuguese 
patients with a clinical diagnosis of Gilbert and Crigler-Najjar syndromes. Blood Cells Molecules and Disease, (in press).

[18] J.K. Ritter, M.T. Yeatman, C. Kaiser, B. Gridelli, I.S. Owens, A phenylalanine codon deletion at the UGT1 gene complex locus of a Crigler-Najjar type I patient generates a $\mathrm{pH}$-sensitive bilirubin UDPglucuronosyltransferase, J. Biol. Chem. 268 (1993) 23573-23579.

[19] J. Seppen, P.J. Bosma, B.G. Goldhoorn, C.T. Bakker, J.R. Chowdhury, P.L. Jansen, R. Oude, P. Elferink, Discrimination between Crigler-Najjar type I and II by expression of mutant bilirubin uridine diphosphate glucurononosyltransferase, J. Clin. Invest. 94 (1994) 2385-2391.

[20] P.J. Bosma, B. Goldhoorn, R.P. Oude Elferink, M. Sinaasappel, B.A. Oostra, P.L. Jansen, A mutation in bilirubin uridine $5^{\prime}$-diphosphate glucuronosyltransferase isoform 1 causing Crigler-Najjar syndrome type II, Gastroenterology 105 (1993) 216-220.

[21] A. Iolascon, A. Meloni, B. Coppola, M.C. Rosatelli, Crigler-Najjar syndrome type II resulting from three different mutations in the bilirubin uridine 5'-diphosphate-glucuronosyltransferase (UGT1A1) gene, J. Med. Genet. 37 (2000) 712-713.

[22] O. Koiwai, M. Nishizawa, K. Hasada, S. Aono, Y. Adachi, N. Mamiya, H. Sato, Gilbert's syndrome is caused by a heterozygous missense mutation in the gene for bilirubin UDP-glucuronosyltransferase, Hum. Mol. Genet. 4 (1995) $1183-1186$.

[23] S. Aono, Y. Yamada, H. Keino, Y. Sasaoka, T. Nakagawa, S. Onishi, S. Mimura, O. Koiwai, H. Sato, A new type of defect in the gene for bilirubin uridine $5^{\prime}$-diphosphate-glucuronosyltransferase in a patient with CriglerNajjar syndrome type I, Pediatr. Res. 35 (1994) 629-632.

[24] P. Labrune, A. Myara, M. Hadchouel, F. Ronchi, O. Bernard, F. Trivin, N.R. Chowdhury, J.R. Chowdhury, A. Munnich, M. Odievre, Genetic heterogeneity of Crigler-Najjar type I: a study of 14 cases, Hum. Genet. 94 (1994) 693-697.

[25] B.S. Sappal, S.S. Gosh, B. Sheneider, A. Kadakol, J.R. Chowdhury, N.R. Chowdhury, A novel intronic mutation results in the use of a cryptic splice acceptor site within the coding region of UGT1A1, causing CriglerNajjar syndrome type I, Mol. Genet. Metab. 75 (2002) 134-142.

[26] M. Ciotti, F. Chen, F.F. Rubaltelli, I.S. Owens, Coding defect and TATA box mutation at the bilirubin UDP-glucuronosyltransferase gene cause Crigler-Najjar type I disease, Biochim. Biophys. Acta 1407 (1998) $40-50$.
[27] L.T. Erps, J.K. Ritter, J.H. Hersh, D. Blossom, N.C. Martin, I.S. Owens, Identification of two single base substitutions in the UGT1 gene locus which abolish bilirubin uridine diphosphate glucuronosyltransferase activity in vitro, J. Clin. Invest. 93 (1994) 564-570.

[28] P.J. Bosma, J.R. Chowdhury, T.J. Huang, P. Lahiri, R.P. Elferink, H.H Van Es, M. Lederstein, P.F. Whitington, P.L. Jansen, N.R. Chowdhury, Mechanisms of inherited deficiencies of multiple UDP-glucuronosyltransferase isoforms in two patients with Crigler-Najjar syndrome type I, FASEB J. 6 (1992) 2859-2863.

[29] N. Moghrabi, D.J. Clarke, M. Boxer, B. Burchell, Identification of an Ato-G missense mutation in exon 2 of the UGT1 gene complex that causes Crigler-Najjar syndrome type 2, Genomics 18 (1993) 171-173.

[30] N. Moghrabi, D.J. Clarke, B. Burchell, M. Boxer, Cosegregation of intragenic markers with a novel mutation that causes Crigler-Najjar syndrome type I: implications in carrier detection and prenatal diagnosis, Am. J. Hum. Genet. 53 (1993) 722-729.

[31] C.S. Huang, G.A. Luo, M.J. Huang, E.S. Chen, T.H. Young, Y.C. Chao, A novel compound heterozygous variation of the uridine-diphosphoglucuronosyltransferase 1A1 gene that causes Crigler-Najjar Syndrome type II, Pharmacogenetics 11 (2001) 639-642.

[32] P. Labrune, A. Myara, J. Chalas, B. Le Bihan, L. Capel, J. Francoual, Association of a homozygous (TA)8 promoter polymorphism and a N400D mutation of UGT1A1 in child with Crigler-Najjar type II syndrome, Hum. Mutat. 20 (2002) 399-401.

[33] Y. Maruo, E. Serdaroglu, M. Iwai, H. Takahashi, A. Mori, M. Bak, S. Calkavur, H. Sato, Y. Takeuchi, A novel missense mutation of the bilirubin UDP-glucuronosyltransferase gene in a Turkish patient with Crigler-Najjar syndrome type I, J. Pediatr. Gastroenterol. Nutr. 37 (2003) 627-630.

[34] N. Chalasani, N.R. Chowdhury, J.R. Chowdhury, T.D. Boyer, Kernictus in an adult who is heterozygous for Crigler-Najjar syndrome and homozygous for Gilbert-type genetic defect, Gastroenterology 112 (1997) 2099-2103.

[35] S. Aono, Y. Yamada, H. Keino, N. Hanada, T. Nakagawa, Y. Sasaoka, T. Yazawa, H. Sato, O. Koiwai, Identification of defect in the genes for bilirubin UDP-glucuronosyl-transferase in a patient with CriglerNajjar syndrome type II, Biochem. Biophys. Res. Commun. 197 (1993) 1239-1244. 